\section{NON-TOXIC DIFFUSE GOITRE}

\section{FACTORS INFLUENCING THE EFFECT OF THYROID * MEDICATION}

BY

I. B. HALES, M.B., M.R.C.P.

\section{J. MYHILL, M.Sc.}

T. S. REEVE, M.B., F.A.C.S.

AND

\section{F. F. RUNDLE, M.D., F.R.C.S.}

From the Unit of Clinical Investigation, the Royal North Shore Hospital of Sydney, Sydney, Australia

The use of thyroid preparations to reduce the size of non-toxic goitres is well established, as is their use in differentiating between high ${ }^{131}$ l uptake rates due to thyrotoxicosis and those occurring in non-toxic goitres (Greer and Smith, 1954 ; Werner and Spooner, 1955). It would seem reasonable to expect that the amount by which the thyroidal ${ }^{131} 1$ uptake can be suppressed by thyroid preparations might be an index of the likelihood of reducing goitre size by their administration. Other factors which might affect the response to the thyroid medication are duration of the goitre, the initial ${ }^{131} I$ uptake rate, and the size of the goitre. The aim of this study was to assess the significance of these factors in the response of goitres to thyroid preparations.

\section{Methods}

The patients studied were referred for investigation to a thyroid investigation clinic which serves an essentially non-endemic and non-iodine-deficient area. Only patients proved euthyroid, with diffuse goitres, were included; nodular goitres were excluded as it is often difficult to differentiate between changes in size of nodules and of the goitre as a whole.

Initially each patient had a ${ }^{131} \mathbf{l}$ uptake rate $\left(\mathrm{k}_{1}\right)$ determined one hour after the intravenous injection of radioiodine (Oddie et al., 1955). A suppression test was then performed by administering either thyroxine $\left(\mathrm{T}_{4}\right)(0.4$ $\mathrm{mg}$./day for 21 days) or triiodothyronine $\left(T_{3}\right)(120-150$ $\mu \mathrm{g} . /$ day for seven days) and measuring a second ${ }^{131} \mathrm{I}$ uptake rate on the 21 st or 7 th day respectively (Oddie et al., 1960a ; Hales et al., 1961). The change in ${ }^{131} I$ uptake rate was assessed as the ratio of uptake rate before medication to the uptake rate during $T_{4}$ or $T_{3}$ administration. This ratio is referred to as the "suppression value." A high suppression value therefore means that there is a large fall in ${ }^{131} 1$ uptake rate during $T_{4}$ or $T_{3}$ administration. For statistical analysis the logarithm of this ratio-that is,

$\log _{10} \frac{{ }^{131} I \text { uptake rate before medication }}{{ }^{131} I \text { uptake rate during } T_{3} \text { or } T_{4} \text { administration }}=x$ has been used as it has been shown to be normally distributed (Oddie et al., 1960a).

The treatment consisted of the administration of thyroxine $0.3 \mathrm{mg}$./ day or dried thyroid $2 \frac{1}{2}-3 \mathrm{gr}$. $(0.16-$ $0.2 \mathrm{~g}$.)/day for a period of not less than three months.

Assessment of the goitre size was made initially and at the end of three months. Goitre sizes were classified as follows: $0=$ no enlargement of the thyroid, or with only the isthmus palpable; $+1=$ lateral lobes clearly palpable but not visible; $+2=$ moderate and visible enlargement of the thyroid; and $+3=$ considerable palpable and visible enlargement. Changes were considered only if the goitre size definitely changed from one classification to another. The duration of the goitre was determined by direct questioning.

\section{Results}

Of 81 patients treated with thyroid compounds, 40 (49\%) showed complete disappearance of the goitre, $32(40 \%)$ showed a clear decrease in the size of the goitre, and $9(11 \%)$ had no significant change in goitre size (Table I). The age and sex distribution are shown in Fig. 1.

Considering the results as classified according to initial goitre size, large goitres were found to have higher initial uptake rates, lower suppression values, and higher 131I uptake rates during suppression (Fig. 2). Analysis of the logarithms of the uptake rate (y) was used because this function of the uptake rate has a normal distribution (Oddie et al., 1960b). The 131I uptake rate during suppression is significantly higher in goitre size +2 than in $+1(P<0.01)$. There were only five patients with +3 goitres and this probably explains the inability to demonstrate a statistical difference between these and the smaller goitres. The duration of goitre was not significantly correlated with goitre size.

Considering next the change in goitre size, reduction following thyroid medication was not related to the initial size of the goitre, the duration of the goitre, the initial ${ }^{131} I$ uptake rate, or the ${ }^{131} I$ uptake rate during suppression (Table II).

However, suppression values in those patients whose goitres diminished in size on thyroid medication was

TABLE I.-Reduction in Goitre Size During Administration of Thyroid Preparations

\begin{tabular}{c|c|c|c|c}
\hline \multirow{2}{*}{$\begin{array}{c}\text { Final } \\
\text { Size }\end{array}$} & \multicolumn{3}{|c|}{ Initial Size } & Total \\
\cline { 2 - 4 } & +1 & +2 & +3 & \\
\hline 0 & 35 & 5 & - & 40 \\
+1 & 5 & 27 & 2 & 34 \\
+2 & -3 & - & - & 7 \\
\hline & -3 & 36 & 5 & 81
\end{tabular}

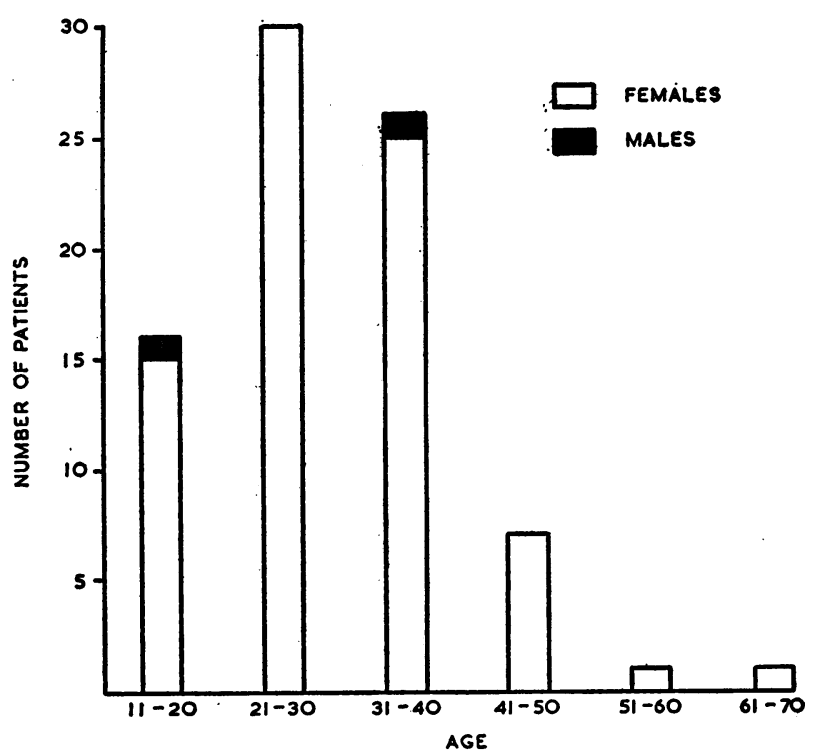

Fig. 1.-Age and sex distribution. 
greater-that is, there was a greater fall in the uptake rate-than in those whose goitres failed to respond to medication $(\mathrm{P}<0.05)$ (Table II).

\section{Discussion}

A large proportion ( $89 \%$ ) of non-toxic diffuse goitres were reduced in size by the administration of thyroid preparations. The chances of such reduction were in no way affected by the length of time that the goitre had existed prior to starting treatment, nor did the initial size of the goitre affect the chances of reduction in size, although the smaller goitres were more likely to disappear completely.

Although the response can often be assessed after one month of treatment, two patients whose goitres showed no reduction at this time subsequently demonstrated definite reduction. Only one patient who showed no change in goitre size after three months showed subsequent decrease after continued administration of thyroid compounds. No difference could be detected between the response to dried thyroid and to thyroxine.

The occurrence of higher initial and suppressed ${ }^{131}$ I uptake rates and lower suppression values with larger goitre sizes is of interest. The results suggest either a constitutional difference in the larger glands or an effect of the mass of functioning tissue. In the latter case the suppression value and the suppressed uptake rate may be brought into line with those in small goitres by increasing the dose of the suppressing agent. It

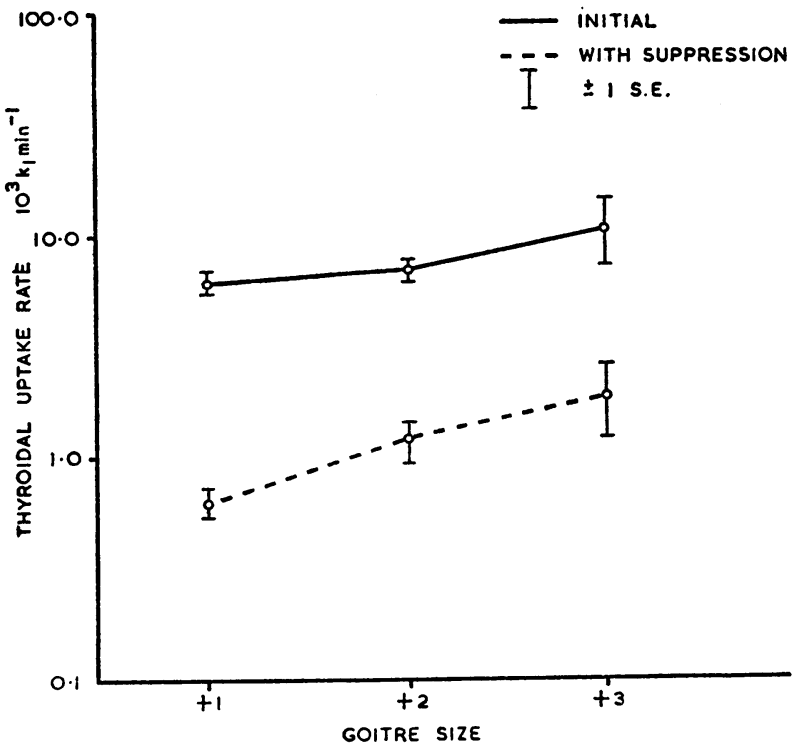

Fic. 2.-Uptake rates and their relationship to various goitre sizes.

TABLE II.-Uptake and Suppressibility Related to Reduction in Goitre Size

\begin{tabular}{|c|c|c|c|c|c|}
\hline \multicolumn{4}{|c|}{ Quantity } & $\begin{array}{c}\text { Reduction in } \\
\text { Goitre Size }\end{array}$ & $\begin{array}{l}\text { No Change } \\
\text { in Size }\end{array}$ \\
\hline $\begin{array}{l}\text { Mean initial uptake rat } \\
\text { Mean } y_{1}=\log \left(10^{3} \mathrm{k}_{1} \text { in }\right. \\
\text { S.E. of mean } y_{1} \quad \ldots \\
\text { No. of cases }\end{array}$ & $\begin{array}{l}0^{3} \mathrm{k}_{1} \mathrm{~min} \\
\text { l) } \\
\cdots \\
\cdots\end{array}$ & $\begin{array}{l}n^{-1} \\
\cdots \\
\cdots \\
\cdots\end{array}$ & $\begin{array}{l}\cdots \\
\cdots \\
\cdots\end{array}$ & $\begin{array}{l}6 \cdot 61 \\
0.820 \\
0 \cdot 034 \\
70\end{array}$ & $\begin{array}{l}7 \cdot 48 \\
0 \cdot 874 \\
0 \cdot 061 \\
9 \\
\end{array}$ \\
\hline $\begin{array}{l}\text { Mean suppression ratio } \\
\text { Mean } x \text {. } \\
\text { S.E. of mean } \mathbf{x} \\
\text { No. of casss .. }\end{array}$ & $\begin{array}{l}\cdots \\
\cdots \\
\cdots\end{array}$ & $\begin{array}{l}\cdots \\
\cdots \\
\cdots\end{array}$ & $\begin{array}{l}\cdots \\
\cdots \\
\cdots\end{array}$ & $\begin{array}{l}7 \cdot 55 \\
0 \cdot 878 \\
0 \cdot 050 \\
68\end{array}$ & $\begin{array}{l}5 \cdot 88 \\
0 \cdot 769 \\
0 \cdot 056 \\
9 \\
\end{array}$ \\
\hline $\begin{array}{l}\text { Mean duration of goitr } \\
\text { S.E. of mean duration } \\
\text { No. of cases .. }\end{array}$ & $\begin{array}{l}\text { n years } \\
\ldots \\
\ldots\end{array}$ & $\begin{array}{l}\cdots \\
\cdots\end{array}$ & $\begin{array}{l}\cdots \\
\cdots\end{array}$ & $\begin{array}{r}6 \cdot 3 \\
4 \cdot 2\end{array}$ & $\begin{array}{l}4 \cdot 8 \\
2 \cdot 5 \\
7\end{array}$ \\
\hline
\end{tabular}

may therefore be possible to improve the diagnostic limits of the ${ }^{131}$ I thyroidal uptake rates (Oddie et al., 1960b) and of the suppression tests (Oddie et al., 1960a ; Hales et al., 1961) by assessing thase tests in relation to the goitre size.

Those goitres which decrease in size after the administration of thyroid compounds have been shown to have greater suppression values than those failing to respond. It is not possible from these suppression values to determine statistical limits above or below which a predicted goitre response will occur. All that can be said is that if there is a marked fall in thyroidal ${ }^{131} \mathrm{I}$ uptake rate during a suppression test, then the gland is more likely to be reduced in size by the administration of thyroid preparations.

\section{Summary}

In $49 \%$ of 81 patients with non-toxic diffuse goitres the goitre disappeared after dried thyroid or thyroxine administration; in a further $40 \%$ definite reduction in goitre size resulted.

Neither duration of goitre, nor size of goitre, nor initial ${ }^{131}$ I uptake could be related to the response of the goitre size to thyroid medication.

Higher initial uptake rates, lower suppression values, and higher final uptake rates were associated with largersized goitres.

The suppressibility of ${ }^{131} \mathrm{I}$ uptake was more marked in those patients whose goitres were reduced in size than in those whose goitres remained unchanged.

\section{REFERENCES}

Greer, M. A., and Smith, G. E. (1954). J. clin. Endocr., 14, 1374. Hales, I. B., Myhill, J., Oddie, T. H., and Croydon, M. (1961). Ibid., 21, 189.

Oddie, T. H., Meschan, I., and Wortham, J. T. (1955). J. clin. Invest., 34, 95, 106, 1044.

- Rundle. F. F., Thomas, I. D., Hales, I. B., and Catt, B. (1960a). J. clin. Endocr., 20, 1146.

Thomas, I. D., Rundle, F. F., Myhill, J., and Catt, B. (1960b). Ibid., 20, 389.

Werner, S. C., and Spooner, M. (1955). Bull. N.Y. Acad. Med., 31, 137.

Dr. Willard C. RAPPleYe, of New York, who recently received the annual Flexner Award for distinguished service to medical education, wrote in his 1961 report as president of the Josiah Macy, Jr., Foundation: "Probably one of the most important defects in the whole scheme of medical education is the wastage of talent and competence at the end of the hospital residency.... There should be an established program which enables a recent graduate to start in a hospital, group practice, or other medical organization in which he is trained and retained later as a staff member or prepared, as in other professions or walks of life, to move to other established positions." Dr. Rappleye believed that group practice and salaried medical services, including increased numbers of full-time hospital and medical college staff appointments, would increase in the future, and that by and large this trend was a good one. He told Medical Tribune that it provided at least part of the answer to those who claimed that comprehensive medical care for all who need it could be provided only by plans financed and directed by the State. He believed that if the United States medical profession took an intelligent, guiding interest in present developments leading to more group practice, extension of private insurance plans, and greater government financial aid for the medically indigent, all the advantages of State-directed systems could be obtained within the framework of the free-enterprise system. (Medical Tribune, February 12, 1962.) 